\title{
Role of T-Cell Polarization and Inflammation and Their Modulation by n-3 Fatty Acids in Gestational Diabetes and Macrosomia
}

\author{
A. Hichami, ${ }^{1}$ O. Grissa, ${ }^{1,2}$ I. Mrizak, ${ }^{1,2}$ C. Benammar, ${ }^{1,3}$ and N. A. Khan ${ }^{1}$ \\ ${ }^{1}$ INSERM U866, Université de Bourgogne, 21000 Dijon, France \\ ${ }^{2}$ Service de Physiologie et Explorations Fonctionnelles, Faculté de Médecine de Sousse, 4000 Sousse, Tunisia \\ ${ }^{3}$ Laboratoire des Produits Naturels (LAPRONA), Département de Biologie Moléculaire et Cellulaire, Faculté des Sciences, \\ Université Abou Bekr Belkaid, 25000 Tlemcen, Algeria
}

Correspondence should be addressed to A. Hichami; aziz.hichami@u-bourgogne.fr

Received 24 December 2015; Revised 10 April 2016; Accepted 5 May 2016

Academic Editor: Michael B. Zemel

Copyright (c) 2016 A. Hichami et al. This is an open access article distributed under the Creative Commons Attribution License, which permits unrestricted use, distribution, and reproduction in any medium, provided the original work is properly cited.

\begin{abstract}
Th ( $\mathrm{T}$ helper) cells are differentiated into either Th1 or Th2 phenotype. It is generally considered that Th1 phenotype is proinflammatory, whereas Th2 phenotype exerts anti-inflammatory or protective effects. Gestational diabetes mellitus (GDM) has been associated with a decreased Th1 phenotype, whereas macrosomia is marked with high expression of Thl cytokines. Besides, these two pathological situations are marked with high concentrations of inflammatory mediators like tumor necrosis factor$\alpha$ (TNF- $\alpha$ ) and interleukin-6 (IL-6), known to play a pivotal role in insulin resistance. Dietary n-3 polyunsaturated fatty acids (n-3 PUFAs) may exert a beneficial effect by shifting Th1/Th2 balance to a Th2 phenotype and increasing insulin sensitivity. In this paper, we shed light on the role of T-cell malfunction that leads to an inflammatory and pathophysiological state, related to insulin resistance in GDM and macrosomia. We will also discuss the nutritional management of these pathologies by dietary $n-3$ polyunsaturated fatty acids (PUFAs).
\end{abstract}

\section{Introduction}

Maternal diabetes during pregnancy, also called gestational diabetes mellitus (GDM), is an important risk factor for foetal overgrowth, termed macrosomia, which is influenced by maternal hyperglycemia and endocrine status through placental circulation [1].

In humans, macrosomia has generally been defined as a birth weight greater than or equal to the 90th percentile birth weight for gestational age, that is, infants who weigh $>4000 \mathrm{~g}$ at delivery, regardless of gestational age or sex [2-4]. Infants born to diabetic mothers are at an increased risk for hypoglycaemia, respiratory distress syndrome, hyperbilirubinemia, and hypertrophic cardiomyopathy [3]. It seems that maternal hyperglycaemia leads to foetal hyperglycaemia, which stimulates foetal pancreatic islet cells and, consequently, induces foetal hyperinsulinaemia. Moreover, there exists a correlationship between maternal and foetal plasma cholesterol levels in 5-6-month-old human foetuses $[5,6]$. It is noteworthy that several alterations in the metabolism of carbohydrates and lipids, observed in newborn babies of diabetic mothers, also persist postnatally [7-9].

\section{In Utero Programming Is Responsible for Alterations Observed in Adulthood}

It is possible that foetal hyperinsulinaemia may be an endogenous teratogen factor during critical periods of foetal development, leading to permanent structural or functional changes and consequent programming of "metabolic memory." Hyperinsulinemia in utero may affect the induction and activity of various hepatic enzymes associated with fat and carbohydrate metabolism [10]. This phenomenon may be accompanied, in placenta, by modifications in the expression of the transcriptional factors such as sterol 
regulatory element binding protein-1c (SREBP-1c), known to induce expression of genes involved in lipogenesis [11].

In 1995, Barker [12] proposed that disproportionate foetal growth induced by foetal malnutrition, which could happen either in the middle or in a later period of the gestation, programmed coronary diseases in adulthood. The in utero programming seems to create a kind of "metabolic memory" as the physiological abnormalities, observed during the gestational period, are responsible for the induction of diseases associated with the metabolic syndrome such as type 2 diabetes (T2D) and obesity in adulthood. Indeed, in human GDM, there exists a correlationship between GDM and 6-month-old foetal plasma cholesterol levels and other abnormal lipid parameters, including high concentrations of triglycerides (TAG), apoB100, very-low-density lipoprotein (VLDL), and low-density lipoprotein (LDL), which often persist in macrosomia [2].

Leptin, an adipocyte-derived hormone, by decreasing food intake and increasing energy expenditure, stabilizes body adiposity [13]. A transient increase in leptin during neonatal life, called "neonatal leptin surge," has been shown to exert a neurotrophic effect and the development of energyregulation circuits in mouse hypothalamus [14]. Furthermore, experimental premature leptin surge "from day 5.5 to day 10.5 of life" in mice pups led to decreased hypothalamic leptin sensitivity and accelerated weight gain when pups were fed a high-fat diet [15]. In healthy women, both maternal and foetal leptin concentrations were correlated with infant size at birth. Reference [16] reported that leptin levels were always higher in overweight than in normal weight newborns, and plasma leptin level was correlated with birth weight. Hence, it is conceivable that foetal leptin plays a role in in utero programming.

In utero nutritional environment may induce epigenetic alterations in the foetus. Epigenetic regulation is mediated by methylation and acetylation of histones. As far as foetal nutrition is concerned, it has been reported that dietary methyl-group intake (choline, methionine, and folate) during critical periods of development can alter DNA and histone methylation which may result in lifelong changes in gene expression [17]. Hence, these epigenetic mechanisms might contribute to the development of macrosomia and its related adulthood pathologies such as obesity and T2D [18].

Growth factors might be implicated in GDM and in the pathology of macrosomia via materno-foeto-placental axis. We have conducted a clinical study in which we have determined circulating growth factors and the expressions of their genes in placenta in GDM mothers and their macrosomic babies. We observed that serum concentrations of IGF-I, IGF-BP3, EGF, FGF-2, and PDGF-B were higher in GDM dames and their macrosomic babies as compared to their respective controls. Besides, the placental expression of the mRNA of growth factors (FGF-2 or PDGF-B) and growth factor receptors, that is, IGF-IR, EGFR, and PDGFRbeta, was upregulated in GDM women compared to controls [19].

\section{Cell-Mediated Immunity in Diabetic Pregnancy and Macrosomia}

The immune system is composed of two major subdivisions, the innate (phagocytic cells and NK cells) and adaptive immune responses. Though the interactions between innate and adaptive immunity are complex, the innate mechanisms control both the initiation and the type of adaptive response (Th1/Th2). It has been shown that the abnormalities in humoral and cell-mediated immunity in T1D females may persist during pregnancy and, hence, may complicate immune-foetal interaction [20].

About $10 \%$ of all GDM women develop T2D after delivery. Though pancreatic autoimmunity does not seem to represent a typical marker of GDM [21], high prevalence of autoantibodies, such as anti-GAD65 and anti-IA2 antibodies, has been observed in GDM subjects [22]. Maternal transmission of these autoantibodies did not affect diabetic risk in the offspring. On the contrary, it has been reported that foetal exposure to maternal T2D protects offspring, during the first 2 decades of life, from the development of islet autoimmunity and diabetes in the later life [23]. This is explained by the fact that the immune systems of children receiving autoantibodies from their diabetic mothers are primed during foetal life [24]. Such priming is demonstrated by an increase in MHC class II positive lymphocytes in infants of diabetic mothers compared to controls [25].

With regard to T-cell activation, only a few studies are available on the subject [20]. In humans, fully activated Tcells are detected in the cord blood of infants and mothers with T1D, but not in infants from normal mothers [20]. Interleukin-2 (IL-2) is a potent T-cell mitogen. Badr et al. [26] have reported a decrease in T-cell proliferation, associated with a decrease of plasma levels of IL-2 in the offspring of diabetic mothers, as compared to those of control mothers. Also, in rat model, probably because of their priming, ex vivo T-cell proliferation is significantly lower in diabetic pregnant rats and their macrosomic offspring, as compared to control animals [27]. This phenomenon may trigger a decrease in the number of circulating and thymus homing T-cells [26].

In addition, the number of T- and B-cells in the neonates of diabetic mothers was significantly decreased compared to the neonates of healthy mothers [28]. Lapolla et al. [29] reported an increase in the number of lymphocytes but a decrease in natural killer (NK) subset in children from GDM mothers. Another alteration in lymphocyte subset pattern is observed in GDM mothers, who had high number of $\mathrm{CD} 8^{+}$ cells, expressing TCR gamma/delta, and low number of $\mathrm{CD}^{+}$ cells, expressing TCR alpha/beta. Also, infants born to GDM women had higher $\mathrm{CD}^{+}$gamma/delta cells than control babies [21]. This immunological imbalance may correlate with a greater risk for developing T1D, later in life [21].

$\mathrm{T}$ helper (Th) dichotomy in GDM and macrosomia has not yet been well explored. On the basis of production of cytokines, Th cells can be classified into two principal populations, Th1 and Th2 (Figure 1). Th1 cells support cell-mediated immunity and, as a consequence, promote inflammation, cytotoxicity, and delayed-type hypersensitivity, whereas Th2 cells support humoral immunity and downregulate 


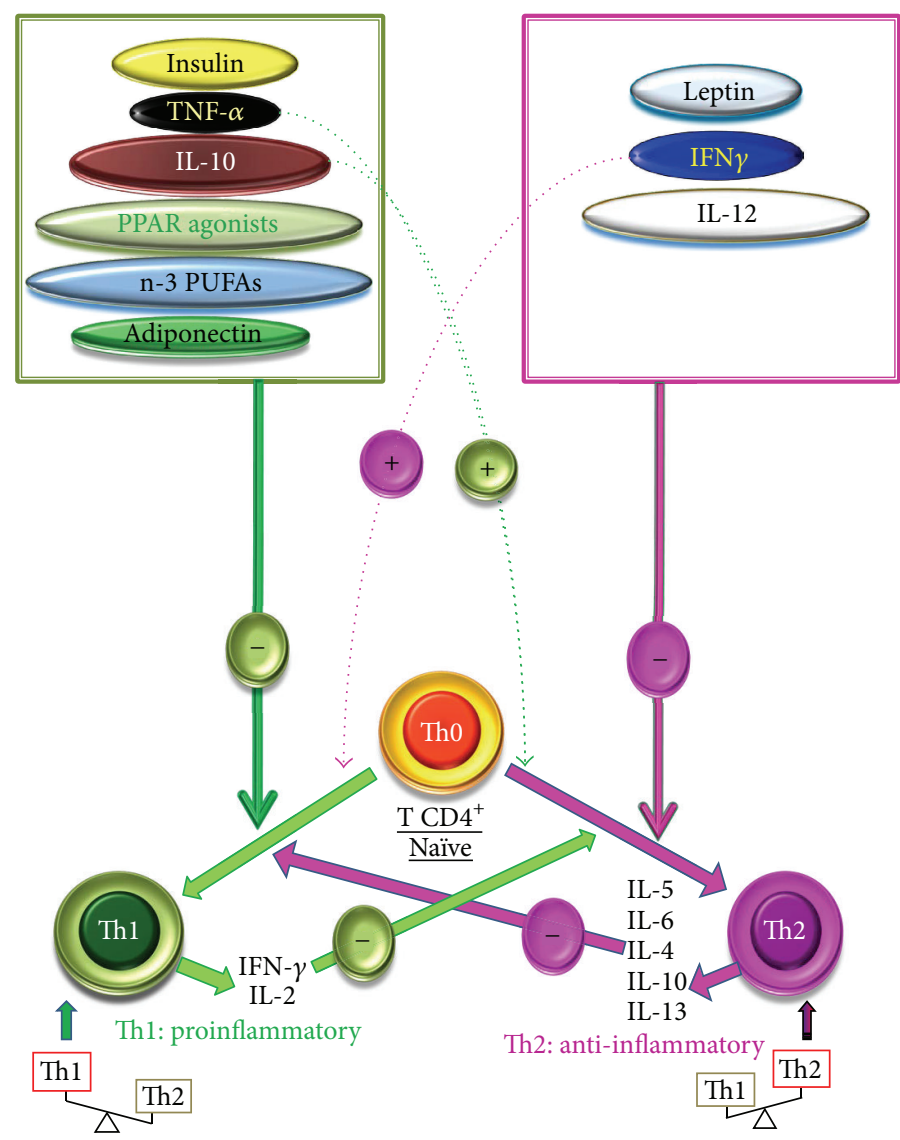

Figure 1: Differentiation of Th0 cells into Th1 and Th2 cells and their modulation. The secretion of their respective cytokines identifies the cells. Th0 cells, which principally secrete IL-2 along with other some cytokines, are differentiated either into Th1, under the action of IL-12 and IFN- $\gamma$, released by the macrophages and NK cells (natural killer), respectively, or into Th2 phenotype by the action of IL- 4 produced by the mastocytes. The IFN- $\gamma$ and IL-10 exert an inhibitory effect on the differentiation of Th1 and Th2 phenotypes, respectively. Insulin, PPAR agonists, and n-3 PUFAs promote the differentiation into Th2 phenotype. Leptin promotes the differentiation into Th1 cells. (+) inducing effect; (-) inhibitory effect.

the inflammatory actions of Th1 cells [30]. Th1 cells secrete IL-2, IFN- $\alpha$, and TNF- $\beta$ while Th2 cells secrete IL-4, IL5, IL-6, IL-10, and IL-13 [31]. Analysis of T-cell markers in placenta showed an increase in T-cell infiltration that expresses GATA3, a marker of Th2 phenotype, in placenta of GDM women [32].

Concerning experimental models of GDM, we would like to mention that we have developed a model by administrating streptozotocin (STZ) to Wistar female rats [2,9]. The rate of success in obtaining macrosomic pups was $75 \%$. We confirmed in this model a decrease in Thl cells, as observed in human GDM [33]. Furthermore, in GDM rat, the decrease in circulating IFN- $\gamma$ was accompanied with an increase in IL-10 (Th2 marker) levels, as compared to control rats [34, 35]. This upregulation of Th2 phenotype in pregnancy is normalized after the delivery [34]. In fact, the shift from the Th1 phenotype to the Th2, during pregnancy, has been shown to encourage vigorous production of antibodies which not only combat infections during pregnancy, but also offer passive immunity to foetus [36]. A low Thl profile in diabetic pregnant rats, associated with successful pregnancy, may also result from the elevated levels of reproductive hormones like human chorionic gonadotrophin (hCG) hormone, whose administration is known to diminish the production of the Thl cytokines [37].

In rats, the upregulated Thl profile in macrosomic animals may be due to difference in physiological status between GDM dames and their offspring [38]. A study conducted on Tunisian women with GDM and their macrosomic babies corroborates these experimental observations [39]. Indeed, the comparison of Th1/Th2 ratio showed an increase in the Th2 phenotype in GDM mothers, whereas an increase in Th1 phenotype was observed in macrosomic infants [39].

The regulatory $\mathrm{T}$ (T-reg) cells represent a specialized population of T-cells $\left(\mathrm{CD} 4^{+} \mathrm{CD} 25^{+}\right)$, known for their properties as potent suppressors of inflammatory responses and for their ability to mediate immune tolerance. T-reg cells induce immune tolerance throughout the production of two immunosuppressive cytokines: TGF- $\beta$ and IL-10 [40]. Both in humans [41] and in mice [42], T-regs cells increase very early in pregnancy, a period which coincides with an intense vascular activity [43]. The importance of T-reg cells in 
the success of pregnancy was demonstrated by Aluvihare et al. [44] who reported that adoptive transfer of T-lymphocytes depleted of T-regs cells into pregnant T-cell-deficient mice led to the rejection of allogeneic foetal units. Furthermore, spontaneous abortion cases and patients with recurrent miscarriage are associated with lower systemic T-reg cells compared to normal pregnancies [45]. In Kuwaiti women, high number of T-cells expressing the activation-associated HLA antigen (CD4 ${ }^{+}$HLA-DR), memory T-cells, and T-reg cells have been observed during GDM $[46,47]$.

The frequency of T-reg cells is significantly higher in children born to T1D mothers than in those born to GDM or normal women $[48,49]$. Indeed, in the case of T1D, the maternal autoimmunity and the transplacental passage of autoGAD antibodies may influence the generation and expansion of foetal T-reg cells, which may suppress the GAD65-specific T-cell responses [48]. Besides, the T-reg cells of children born to T1D mothers exhibit a more pronounced memory phenotype (increased CCR4 expression and downregulation of CD62L), suggesting an early activation of the foetal immune system, as a consequence of maternal autoimmunity [48]. It seems that the suppressive activity of T-reg cells was significantly reduced in GDM patients when compared to healthy pregnancy [50].

It is noteworthy that obesity-induced insulin resistance is associated with the development of a specialized T-reg population in visceral adipose tissue, called "VAT resident T-reg" [51]. Visceral adipose inflammation and insulin resistance have been associated with a dramatic reduction in VAT T-reg cells in several animal models of obesity. T-reg cells, by secreting IL-10, decrease the inflammatory state of adipose tissue and, thereby, improve insulin resistance [52]. Loss-of-function and gain-of-function experiments demonstrated that VAT T-reg cells are indispensable to reducing inflammation and increasing insulin sensitivity [52]. Hence, the implication of VAT resident T-reg cells deserves deep investigations in macrosomia.

\section{T-Cells Present a Defect in Calcium Signaling in Diabetic Pregnancy and Macrosomia}

During T-cell activation, an increase in intracellular free calcium concentrations, $\left[\mathrm{Ca}^{2+}\right] \mathrm{i}$, is one of the earliest events which is triggered as a result of the hydrolysis of phosphatidylinositol-bisphosphate, catalyzed by the phospholipase C (PLC). Hence, PLC gives rise to inositol trisphosphate, which recruits calcium from endoplasmic reticulum pool, and diacylglycerol which activates the protein kinase C. According to capacitive model of calcium entry, first calcium is released via T-cell receptor (TCR) activation from the endoplasmic reticulum (ER) and then it is extruded into the extracellular medium. In turn, the cells refill their intracellular emptied pool by opening calcium channels [49]. Ionomycin opens calcium channels, leading to calcium influx from extracellular medium and thapsigargin (TG) recruits calcium which belongs to endoplasmic reticulum (ER) pool. Interestingly, ionomycin-induced increases in $\left[\mathrm{Ca}^{2+}\right] \mathrm{i}$ in
T-cells of GDM dames and their macrosomic offspring were greater than those in control rats [27]. In $0 \%$ of calcium buffer, TG induces increases in $\left[\mathrm{Ca}^{2+}\right] \mathrm{i}$ exclusively from ER pool and no influx occurs in the absence of calcium from the extracellular medium [53]. Hence, both in $100 \%$ and in $0 \%$ calcium media, TG-induced increases in $\left[\mathrm{Ca}^{2+}\right] \mathrm{i}$ in T-cells are higher in GDM dames and macrosomic rats than those in control animals [27], demonstrating that T-cell calcium signaling is altered in these two pathological situations.

\section{Proinflammatory Adipokines and Cytokines in GDM and Macrosomia}

TNF- $\alpha$ and IL- 6 represent the main inflammatory cytokines increased in the insulin-resistant states of obesity and T2D $[26,54]$. Increasing evidence suggests that GDM is a proinflammatory state similarly to T2D. Monocyte chemotactic protein-1 (MCP-1) is known to be elevated in inflammatory diseases like arthritis and lupus [55]. The elevation of MCP1 in the third trimester of GDM suggests an association between inflammation and GDM [56]. Besides, it has been suggested that hyperglycaemia and its related oxidative stress are usually associated with increased proinflammatory cytokines production $[57,58]$.

Increased concentrations of TNF- $\alpha$ and IL- 6 might not only diminish insulin sensitivity by suppressing insulin signal transduction, but also interfere with the anti-inflammatory effect of insulin (Figure 2) [54, 59]. Indeed, insulin exerts its anti-inflammatory effect by decreasing the production of reactive oxygen species (ROS) from mononuclear cells and nuclear NF- $\kappa$ B translocation [54]. Furthermore, insulin decreases the concentration of MCP-1, PAI-1, and EGR-1 [60]. The in vivo administration of insulin not only decreases the severity of T2D, but also diminishes the levels of MCP1 and C-reactive protein (CRP), the two indicators of the inflammatory state [61]. IL-6 promotes insulin resistance in liver cells [62] and negatively regulates insulin signaling and glucose metabolism in adipocytes [63]. TNF- $\alpha$ inhibits tyrosine phosphorylation of insulin receptor and, thereby, insulin signaling [64]. It has been suggested that the increase in TNF$\alpha$ and IL- 6 in diabetic conditions might be a result of oxidative stress and inflammatory changes caused by hyperglycaemia [65]. IL- 6 and TNF- $\alpha$ are mainly produced by adipose tissues. Indeed, during insulin-resistant state, adipocytes secrete MCP-1 which favors the infiltration of macrophages that, consequently, produce IL- 6 and TNF- $\alpha$ in high quantities (Figure 2) $[66,67]$. We have reported that TNF- $\alpha$ and IL-6 are increased in GDM women [39]. During pregnancy, IL-6 secretion has been proposed to aggravate insulin resistance and participates in the pathogenesis of GDM [59].

Adipocytes secrete a number of molecules, including adiponectin, leptin, and resistin, that modulate peripheral insulin sensitivity [66]. From the immunological point of view, adiponectin exhibits anti-inflammatory properties [66] and leptin polarizes Th cytokine production toward a proinflammatory (Th1) phenotype (Figure 1) [68]. Since adipocytokines may play an important role in the early defects of T2D [69], women with GDM represent an ideal population 


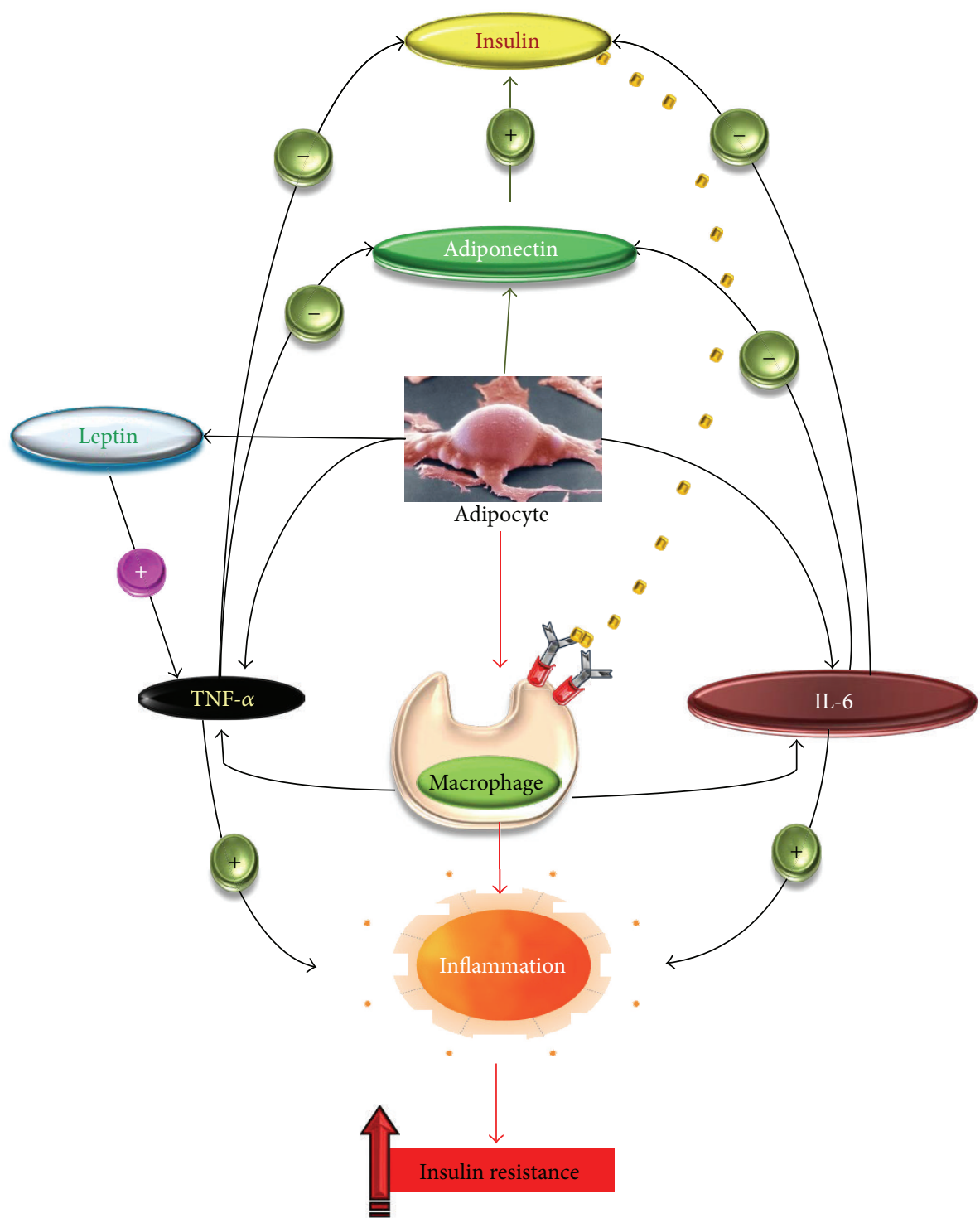

FIGURE 2: Secretion of cytokines and adipokines and their implications in insulin resistance. The adipocytes secrete adipokines (leptin and adiponectin). Proinflammatory cytokines released by macrophages. Leptin contributes to inflammation by increasing the secretion of TNF- $\alpha$. Both TNF- $\alpha$ and IL- 6 antagonize the action of insulin and decrease the secretion of adiponectin which exerts insulin-sensitizing action. $(+)$ inducing effect; (-) inhibitory effect.

model for studying this interrelationship [70]. Leptin is also produced by placenta and involved in weight regulation and lipid metabolism. Contradictory results have been reported on its secretion in GDM. Depending on studies, elevated [71], constant [72], or decreased [73] levels of leptin have been observed in GDM women. Hence, in contrast to obesity which leads to an inflammatory Th1 state, leptin does not play an important role in GDM, marked with Th2 response, probably because of the hormonal status during pregnancy. Besides hyperglycaemia, chronic foetal hypoxia, detected in GDM, may also increase the inflammatory burden incurred by the foetus [74].

\section{6. n-3 PUFAs Exert Beneficial Effects in Macrosomia}

Dietary n-3 PUFAs have been considered as immunosuppressors and, therefore, are used in the management of a number of inflammatory and autoimmune diseases, including rheumatoid arthritis and multiple sclerosis $[75,76]$, as these pathologies are characterized by the presence of activated T-cells and inflammatory cytokines either at the site of tissue injury $[77,78]$ or in blood circulation $[79,80]$. Fat-1 transgenic mice, known to convert endogenous n-6 PUFAs to $n-3$ PUFAs, were protected from diabetes, because of low 
concentrations of TNF- $\alpha$ and IL-1 $\beta$ [81]. Generally, both in animal models and in humans, n-3 PUFAs decrease TNF$\alpha$ and IL- 6 production [82]. n-3 PUFAs exert their effect on the inflammatory gene expression through the inhibition of intracellular signaling pathways that lead to NF- $\kappa \mathrm{B}$ activation [83].

n-3 PUFAs have been shown to suppress mitogenstimulated proliferation of lymphocytes isolated from lymph nodes [84], spleen [85], and lymphatic duct [86], in mice and human beings $[75,85]$. Feeding the n-3 PUFA-diet corrected intracellular calcium homeostasis in T-cells of diabetic pregnant dames and their macrosomic obese rats [27]. We have assessed the Th1/Th2 dichotomy by dietary n-3 PUFAs in diabetic pregnancy and macrosomia. We observed that the n-3 PUFAs-diet upregulated the Th2 profile in GDM rats. In macrosomic offspring, the Thl phenotype is upregulated and an n-3 PUFAs-diet downregulated this phenomenon [33]. In agreement with our finding, Wallace et al. [76] have also observed that feeding fish oil to mice induced a shift in the IFN- $\alpha /$ IL- 4 ratio, by a factor of four, as compared to animals fed the low fat diets. n-3 PUFAs also regulated T-reg functioning. We have investigated the molecular mechanisms by which n-3 PUFAs-diet controls T-reg cell suppressive capacity. We used docosahexaenoic acid (DHA), the end product of $\alpha$-linolenic acid metabolism in animal tissues, and observed that the exposure of T-reg cells to this fatty acid or its in vivo supplementation upregulated TGF- $\beta$ but downregulated IL10 in these cells, suggesting that DHA might be orienting the T-reg cell differentiation toward a Th3 phenotype [87]. Th3 phenotypes that infiltrate decidua are known to prevent abortion and contribute to the success of pregnancy [34].

Furthermore, DHA diminished the suppressive activity of T-reg cells on effector T-cell proliferation. It is now becoming clear that the interaction of Foxp3 with other transcription factors (like NAFT or Runx-1) or histone deacetyltransferase and class II histone deacetylase is critical for the repression of the transcription of IL-2 gene by Foxp3 [88]. Hence, we hypothesized that DHA might downregulate T-reg cell activity, by interfering with the critical downstream components of the Foxp3-driven suppressor pathway. Furthermore, DHA reduced the migration of T-reg cells toward chemokines by downregulating the expression of chemokines receptors (CCR-4 and CXCR-4) in these cells [87].

T-reg cell migration and activity have been found to be associated with mitogen-activated protein kinase (MAPK), that is, ERK1/2, activation [89]. Besides ERK1/2, the phosphatidylinositol-3-kinase (PI3K) and Akt/protein kinase $\mathrm{B}$ (hence referred to as Akt) play a critical role in the Tcell survival, expansion, and differentiation [90]. ERK1/2 and Akt phosphorylation controls the expression of $\mathrm{p} 27^{\mathrm{KIP} 1}$, an inhibitor of cyclinE/cyclinD kinase 2 that regulates cell cycle [91]. We noticed that DHA significantly diminished the MAPK phosphorylation in activated T-reg cells, and this phenomenon was associated with an increase of $\mathrm{p} 27^{\mathrm{KIP} 1}$ in Treg cells. Hence, DHA seems to reinforce the anergic state of T-reg cells [87].

Concerning the molecular mechanism of action of $n-3$ PUFAs, we have previously shown that dietary n-3 PUFAs are incorporated into plasma membrane phospholipids [92]. Hence, we assume that dietary n-3 PUFAs may exert their beneficial action by modulating cell signaling. We have recently shown that $\mathrm{T}$-cell activation and $\mathrm{T}$-cell calcium signaling are altered in diabetic pregnancy and macrosomia, and dietary fish oils, particularly eicosapentaenoic acid (EPA) and DHA, restore these T-cell abnormalities [93]. During cell activation, a modification in the intracellular $\mathrm{pH}$ also plays an important role in the cell cycle progression and, hence, DHA and EPA have been shown to modulate this phenomenon. Dietary n-3 PUFAs, incorporated into plasma membrane, may also give rise to diacylglycerols which, in turn, may modulate cell activation. It has been shown that diacylglycerols, containing EPA and DHA, modulate PKC activation [94], calcium signaling [95], and ERK1/ERK2 phosphorylation [96].

\section{Conclusion}

The incidence of GDM and macrosomia continues to grow worldwide and represents a major public health challenge. Except for genetic factors, physical inactivity and high caloric food are the major causing factors for these pathologies. Based on clinical studies, the Dietary Guidelines for Americans 2005 report [97] and several international and professional organizations [98] have made recommendations for consumption of at least two meals, containing fish, per week or from $0.250 \mathrm{~g}$ to $1 \mathrm{~g}$ of EPA and DHA daily with a $5: 1$ ratio of n- 6 fatty acid/n-3 fatty acid. There is no doubt concerning the beneficial effects of n-3 PUFAs in the improvements of hypertriglyceridemia and the reduction of cardiovascular risk [99]. Thus, the use of these fatty acids in combination with genuine drugs (lipid-lowering, anti-inflammatory, etc.) represents a new therapeutic strategy in fighting against diabetes and obesity.

\section{Abbreviations}

$\begin{array}{ll}\text { Th: } & \text { T helper } \\ \text { TNF- } \alpha: & \text { The tumor necrosis factor- } \alpha \\ \text { IL-6: } & \text { Interleukin-6 } \\ \text { PPAR } \alpha: & \text { Peroxisome proliferator-activated } \\ & \text { receptor alpha } \\ \text { n-3 PUFAs: } & \text { n-3 polyunsaturated fatty acids } \\ \text { GDM: } & \text { Gestational diabetes mellitus } \\ \text { RDS: } & \text { Respiratory distress syndrome } \\ \text { VLDL: } & \text { Very-low-density lipoprotein } \\ \text { LDL: } & \text { Low-density lipoprotein } \\ \text { apoB100: } & \text { Apolipoprotein B 100 } \\ \text { DHA: } & \text { Docosahexaenoic acid } \\ \text { EPA: } & \text { Eicosapentaenoic acid } \\ \text { PMNs: } & \text { Polymorphonuclear neutrophils } \\ \text { NK cells: } & \text { Natural killer cells } \\ \text { T1D: } & \text { Type I diabetic } \\ \text { Anti-IA2: } & \text { Islet Cell Autoantigen 512 Antibodies } \\ \text { IDDM: } & \text { Insulin-dependent diabetes mellitus } \\ \text { TCR alpha/beta: } & \text { Human T-cell receptor } \\ \text { STZ: } & \text { Streptozotocin } \\ \text { IFN- } \alpha: & \text { Interferon alpha } \\ \text { Foxp3: } & \text { Forkhead box P3 }\end{array}$


CTLA-4: Cytotoxic T-Lymphocyte Antigen 4

CCR4: C-C chemokine receptor type 4

PLC: $\quad$ Phospholipase C

TCR: T-cell receptor

MCP-1: Monocyte chemotactic protein-1

PAI-1: Plasminogen activator inhibitor

EGR-1: Early growth response protein-1

Runx-1: Runt-related transcription factor 1

ERK1/2: Extracellular signal-regulated kinases 1/2

PI3K: Phosphatidylinositol-3-kinase.

\section{Competing Interests}

All of the authors have nothing to declare as far as the conflict of interests is concerned.

\section{Acknowledgments}

The authors express their sincere thanks to Mrs. EVA Pop Askri for English language corrections.

\section{References}

[1] N. A. Khan, "Role of lipids and fatty acids in macrosomic offspring of diabetic pregnancy," Cell Biochemistry and Biophysics, vol. 48, no. 2-3, pp. 79-88, 2007.

[2] H. Merzouk, S. Madani, A. Hichami, J. Prost, J. Belleville, and N. A. Khan, "Age-related changes in fatty acids in obese offspring of streptozotocin-induced diabetic rats," Obesity Research, vol. 10, no. 7, pp. 703-714, 2002.

[3] A. A. Meshari, S. De Silva, and I. Rahman, "Fetal macrosomiamaternal risks and fetal outcome," International Journal of Gynecology and Obstetrics, vol. 32, no. 3, pp. 215-222, 1990.

[4] J. M. Miller Jr., H. L. Brown, J. G. Pastorek II, and H. A. Gabert, "Fetal overgrowth: diabetic versus nondiabetic," Journal of Ultrasound in Medicine, vol. 7, no. 10, pp. 577-579, 1988.

[5] C. Napoli, F. P. D’Armiento, F. P. Mancini et al., "Fatty streak formation occurs in human fetal aortas and is greatly enhanced maternal, hypercholesterolemia. Intimal accumulation of low density lipoprotein and its oxidation precede monocyte recruitment into early atheroeclerotic lesions," Journal of Clinical Investigation, vol. 100, no. 11, pp. 2680-2690, 1997.

[6] R. A. Vogel, M. C. Corretti, and G. D. Plotnick, "Effect of a single high-fat meal on endothelial function in healthy subjects," American Journal of Cardiology, vol. 79, no. 3, pp. 350-354, 1997.

[7] H. Přibylová and L. Dvořáková, "Long-term prognosis of infants of diabetic mothers: relationship between metabolic disorders in newborns and adult offspring," Acta Diabetologica, vol. 33, no. 1, pp. 30-34, 1996.

[8] H. Merzouk, S. Madani, J. Prost, B. Loukidi, M. MeghelliBouchenak, and J. Belleville, "Changes in serum lipid and lipoprotein concentrations and compositions at birth and after 1 month of life in macrosomic infants of insulin-dependent diabetic mothers," European Journal of Pediatrics, vol. 158, no. 9, pp. 750-756, 1999.

[9] H. Merzouk, S. Madani, D. C. Sari, J. Prost, M. Bouchenak, and J. Belleville, "Time course of changes in serum glucose, insulin, lipids and tissue lipase activities in macrosomic offspring of rats with streptozotocin-induced diabetes," Clinical Science, vol. 98, no. 1, pp. 21-30, 2000.
[10] A. L. Fowden, "The role of insulin in prenatal growth," Journal of Developmental Physiology, vol. 12, no. 4, pp. 173-182, 1989.

[11] F. Foufelle and P. Ferré, "New perspectives in the regulation of hepatic glycolytic and lipogenic genes by insulin and glucose: a role for the transcription factor sterol regulatory element binding protein-1c," Biochemical Journal, vol. 366, no. 2, pp. 377391, 2002.

[12] D. J. P. Barker, "Fetal origins of coronary heart disease," British Medical Journal, vol. 311, no. 6998, pp. 171-174, 1995.

[13] J. M. Friedman and J. L. Halaas, "Leptin and the regulation of body weight in mammals," Nature, vol. 395 , no. 6704, pp. 763770, 1998.

[14] S. G. Bouret, S. J. Draper, and R. B. Simerly, "Trophic action of leptin on hypothalamic neurons that regulate feeding," Science, vol. 304, no. 5667, pp. 108-110, 2004.

[15] S. Yura, H. Itoh, N. Sagawa et al., "Neonatal exposure to leptin augments diet-induced obesity in leptin-deficient ob/ob mice," Obesity, vol. 16, no. 6, pp. 1289-1295, 2008.

[16] M. Maffei, L. Volpe, G. Di Cianni et al., "Plasma leptin levels in newborns from normal and diabetic mothers," Hormone and Metabolic Research, vol. 30, no. 9, pp. 575-580, 1998.

[17] S. H. Zeisel, "Dietary choline deficiency causes DNA strand breaks and alters epigenetic marks on DNA and histones," Mutation Research/Fundamental and Molecular Mechanisms of Mutagenesis, vol. 733, no. 1-2, pp. 34-38, 2012.

[18] J. A. Joles, "Crossing borders: linking environmental and genetic developmental factors," Microcirculation, vol. 18, no. 4, pp. 298303, 2011.

[19] O. Grissa, A. Yessoufou, I. Mrisak et al., "Growth factor concentrations and their placental mRNA expression are modulated in gestational diabetes mellitus: possible interactions with macrosomia," BMC Pregnancy and Childbirth, vol. 10, article 7, 2010.

[20] C. Giordano, "Immunobiology of normal and diabetic pregnancy," Immunology Today, vol. 11, no. 9, pp. 301-303, 1990.

[21] A. Lapolla, M. G. Dalfrà, M. Sanzari et al., "Lymphocyte subsets and cytokines in women with gestational diabetes mellitus and their newborn," Cytokine, vol. 31, no. 4, pp. 280-287, 2005.

[22] C. Murgia, M. Orrù, E. Portoghese et al., "Autoimmunity in gestational diabetes mellitus in Sardinia: a preliminary casecontrol report," Reproductive Biology and Endocrinology, vol. 6, article 24, 2008.

[23] J. H. Warram, B. C. Martin, and A. S. Krolewski, "Risk of IDDM in children of diabetic mothers decreases with increasing maternal age at pregnancy," Diabetes, vol. 40, no. 12, pp. 1679$1684,1991$.

[24] K. Koczwara, E. Bonifacio, and A.-G. Ziegler, "Transmission of maternal islet antibodies and risk of autoimmune diabetes in offspring of mothers with type 1 diabetes," Diabetes, vol. 53, no. 1, pp. 1-4, 2004.

[25] U. Di Mario, F. Dotta, P. Gargiulo et al., "Immunology in diabetic pregnancy: activated T cells in diabetic mothers and neonates," Diabetologia, vol. 30, no. 2, pp. 66-71, 1987.

[26] G. Badr, S. Alwasel, H. Ebaid, M. Mohany, and I. Alhazza, "Perinatal supplementation with thymoquinone improves diabetic complications and T cell immune responses in rat offspring," Cellular Immunology, vol. 267, no. 2, pp. 133-140, 2011.

[27] B. Guermouche, A. Yessoufou, N. Soulimane et al., "n-3 fatty acids modulate T-cell calcium signaling in obese macrosomic rats," Obesity Research, vol. 12, no. 11, pp. 1744-1753, 2004. 
[28] U. Roll, J. Scheeser, E. Standl, and A. G. Ziegler, "Alerations of lymphocyte subsets in children of diabetic mothers," Diabetologia, vol. 37, no. 11, pp. 1132-1141, 1994.

[29] A. Lapolla, M. C. Sanzari, F. Zancanaro et al., "A study on lymphocyte subpopulation in diabetic mothers at delivery and in their newborn," Diabetes, Nutrition and MetabolismClinical and Experimental, vol. 12, no. 6, pp. 394-399, 1999.

[30] J. Rengarajan, S. J. Szabo, and L. H. Glimcher, "Transcriptional regulation of Th1/Th2 polarization," Immunology Today, vol. 21, no. 10, pp. 479-483, 2000.

[31] R. S. Liblau, S. M. Singer, and H. O. McDevitt, “Th1 and Th2 $\mathrm{CD} 4^{+} \mathrm{T}$ cells in the pathogenesis of organ-specific autoimmune diseases," Immunology Today, vol. 16, no. 1, pp. 34-38, 1995.

[32] I. Mrizak, O. Grissa, B. Henault et al., "Placental infiltration of inflammatory markers in gestational diabetic women," General Physiology and Biophysics, vol. 33, no. 2, pp. 169-176, 2014.

[33] N. A. Khan, A. Yessoufou, M. Kim, and A. Hichami, "N-3 fatty acids modulate Th1 and Th2 dichotomy in diabetic pregnancy and macrosomia," Journal of Autoimmunity, vol. 26, no. 4, pp. 268-277, 2006.

[34] R. Raghupathy, "Pregnancy: success and failure within the Th1/Th2/Th3 paradigm," Seminars in Immunology, vol. 13, no. 4, pp. 219-227, 2001.

[35] M. Makhseed, R. Raghupathy, F. Azizieh, A. Omu, E. AlShamali, and L. Ashkanani, "Th1 and Th2 cytokine profiles in recurrent aborters with successful pregnancy and with subsequent abortions," Human Reproduction, vol. 16, no. 10, pp. 2219-2226, 2001.

[36] G. Reinhard, A. Noll, H. Schlebusch, P. Mallmann, and A. V. Ruecker, "Shifts in the TH1/TH2 balance during human pregnancy correlate with apoptotic changes," Biochemical and Biophysical Research Communications, vol. 245, no. 3, pp. 933938, 1998.

[37] N. A. Khan, A. Khan, H. F. J. Savelkoul, and R. Benner, "Inhibition of diabetes in NOD mice by human pregnancy factor," Human Immunology, vol. 62, no. 12, pp. 1315-1323, 2001.

[38] N. A. Soulimane-Mokhtari, B. Guermouche, A. Yessoufou et al., "Modulation of lipid metabolism by n-3 polyunsaturated fatty acids in gestational diabetic rats and their macrosomic offspring," Clinical Science, vol. 109, no. 3, pp. 287-295, 2005.

[39] J.-M. Atègbo, O. Grissa, A. Yessoufou et al., "Modulation of adipokines and cytokines in gestational diabetes and macrosomia," The Journal of Clinical Endocrinology and Metabolism, vol. 91, no. 10, pp. 4137-4143, 2006.

[40] Y. Sasaki, M. Sakai, S. Miyazaki, S. Higuma, A. Shiozaki, and S. Saito, "Decidual and peripheral blood $\mathrm{CD} 4{ }^{+} \mathrm{CD} 25^{+}$regulatory $\mathrm{T}$ cells in early pregnancy subjects and spontaneous abortion cases," Molecular Human Reproduction, vol. 10, no. 5, pp. 347353, 2004.

[41] S. Sakaguchi, "Naturally arising Foxp3-expressing CD $25^{+} \mathrm{CD} 4^{+}$ regulatory $\mathrm{T}$ cells in immunological tolerance to self and nonself," Nature Immunology, vol. 6, no. 4, pp. 345-352, 2005.

[42] K. Matrougui, A. E. Zakaria, M. Kassan et al., "Natural regulatory $\mathrm{T}$ cells control coronary arteriolar endothelial dysfunction in hypertensive mice," The American Journal of Pathology, vol. 178, no. 1, pp. 434-441, 2011.

[43] C. Thuere, M. L. Zenclussen, A. Schumacher et al., "Kinetics of regulatory T cells during murine pregnancy," American Journal of Reproductive Immunology, vol. 58, no. 6, pp. 514-523, 2007.

[44] V. R. Aluvihare, M. Kallikourdis, and A. G. Betz, "Regulatory T cells mediate maternal tolerance to the fetus," Nature Immunology, vol. 5, no. 3, pp. 266-271, 2004.
[45] M. J. Jasper, K. P. Tremellen, and S. A. Robertson, "Primary unexplained infertility is associated with reduced expression of the T-regulatory cell transcription factor Foxp3 in endometrial tissue," Molecular Human Reproduction, vol. 12, no. 5, pp. 301308, 2006.

[46] F. F. Mahmoud, D. D. Haines, H. T. Abul, A. E. Omu, and M. B. Abu-donia, "Butyrylcholinesterase activity in gestational diabetes: correlation with lymphocyte subpopulations in peripheral blood," American Journal of Reproductive Immunology, vol. 56, no. 3, pp. 185-192, 2006.

[47] F. Mahmoud, H. Abul, A. Omu, and D. Haines, "Lymphocyte sub-populations in gestational diabetes," American Journal of Reproductive Immunology, vol. 53, no. 1, pp. 21-29, 2005.

[48] B. C. Holm, J. Svensson, C. Åkesson et al., "Evidence for immunological priming and increased frequency of $\mathrm{CD}^{+}$ $\mathrm{CD} 25^{+}$cord blood $\mathrm{T}$ cells in children born to mothers with type 1 diabetes," Clinical and Experimental Immunology, vol. 146, no. 3, pp. 493-502, 2006.

[49] J. W. Putney Jr., "Type 3 inositol 1,4,5-trisphosphate receptor and capacitative calcium entry," Cell Calcium, vol. 21, no. 3, pp. 257261, 1997.

[50] L. Schober, D. Radnai, J. Spratte et al., "The role of regulatory T cell (Treg) subsets in gestational diabetes mellitus," Clinical and Experimental Immunology, vol. 177, no. 1, pp. 76-85, 2014.

[51] D. Cipolletta, D. Kolodin, C. Benoist, and D. Mathis, “Tissular tregs: a unique population of adipose-tissue-resident Foxp $3^{+} \mathrm{CD} 4^{+} \mathrm{T}$ cells that impacts organismal metabolism," Seminars in Immunology, vol. 23, no. 6, pp. 431-437, 2011.

[52] M. Feuerer, L. Herrero, D. Cipolletta et al., "Lean, but not obese, fat is enriched for a unique population of regulatory $\mathrm{T}$ cells that affect metabolic parameters," Nature Medicine, vol. 15, no. 8, pp. 930-939, 2009.

[53] S. C. Chow and M. Jondal, " $\mathrm{Ca}^{2+}$ entry in T cells is activated by emptying the inositol 1,4,5-trisphosphate sensitive $\mathrm{Ca}^{2+}$ pool," Cell Calcium, vol. 11, no. 10, pp. 641-646, 1990.

[54] P. Dandona, A. Aljada, and A. Bandyopadhyay, "Inflammation: the link between insulin resistance, obesity and diabetes," Trends in Immunology, vol. 25, no. 1, pp. 4-7, 2004.

[55] B. J. Rollins, "Monocyte chemoattractant protein 1: a potential regulator of monocyte recruitment in inflammatory disease," Molecular Medicine Today, vol. 2, no. 5, pp. 198-204, 1996.

[56] K. Klein, M. Satler, M. Elhenicky et al., "Circulating levels of MCP-1 are increased in women with gestational diabetes," Prenatal Diagnosis, vol. 28, no. 9, pp. 845-851, 2008.

[57] E. M. Sternberg, G. P. Chrousos, R. L. Wilder, and P. W. Gold, "The stress response and the regulation of inflammatory disease," Annals of Internal Medicine, vol. 117, no. 10, pp. 854866, 1992.

[58] K. Esposito, F. Nappo, R. Marfella et al., "Inflammatory cytokine concentrations are acutely increased by hyperglycemia in humans: role of oxidative stress," Circulation, vol. 106, no. 16, pp. 2067-2072, 2002.

[59] F. Yu, Y.-M. Xue, C.-Z. Li et al., "Association of serum interleukin- 6 and high-sensitivity C-reactive protein levels with insulin resistance in gestational diabetes mellitus," Nan Fang Yi Ke Da Xue Xue Bao, vol. 27, no. 6, pp. 799-801, 2007.

[60] T. K. Hansen, S. Thiel, S. T. Knudsen et al., "Elevated levels of mannan-binding lectin in patients with type 1 diabetes," The Journal of Clinical Endocrinology \& Metabolism, vol. 88, no. 10, pp. 4857-4861, 2003. 
[61] K. Takebayashi, Y. Aso, and T. Inukai, "Initiation of insulin therapy reduces serum concentrations of high-sensitivity Creactive protein in patients with type 2 diabetes," Metabolism: Clinical and Experimental, vol. 53, no. 6, pp. 693-699, 2004.

[62] J. H. Kim, R. A. Bachmann, and J. Chen, "Interleukin-6 and insulin resistance," Vitamins \& Hormones, vol. 80, pp. 613-633, 2009.

[63] M. Kuzmicki, B. Telejko, J. Szamatowicz et al., "High resistin and interleukin-6 levels are associated with gestational diabetes mellitus," Gynecological Endocrinology, vol. 25, no. 4, pp. 258263, 2009.

[64] G. S. Hotamisligil, D. L. Murray, L. N. Choy, and B. M. Spiegelman, "Tumor necrosis factor $\alpha$ inhibits signaling from the insulin receptor," Proceedings of the National Academy of Sciences of the United States of America, vol. 91, no. 11, pp. 48544858, 1994.

[65] M. E. E. Shams, M. M. H. Al-Gayyar, and E. A. M. E. Barakat, "Type 2 diabetes mellitus-induced hyperglycemia in patients with NAFLD and normal LFTs: relationship to lipid profile, oxidative stress and pro-inflammatory cytokines," Scientia Pharmaceutica, vol. 79, no. 3, pp. 623-634, 2011.

[66] F. Lago, C. Dieguez, J. Gómez-Reino, and O. Gualillo, "Adipokines as emerging mediators of immune response and inflammation," Nature Clinical Practice Rheumatology, vol. 3, no. 12, pp. 716-724, 2007.

[67] P. Dandona, A. Aljada, P. Mohanty et al., "Insulin inhibits intranuclear nuclear factor $\kappa \mathrm{B}$ and stimulates $\mathrm{I} \kappa \mathrm{B}$ in mononuclear cells in obese subjects: evidence for an anti-inflammatory effect?" Journal of Clinical Endocrinology and Metabolism, vol. 86, no. 7, pp. 3257-3265, 2001.

[68] B. Mattioli, E. Straface, M. G. Quaranta, L. Giordani, and M. Viora, "Leptin promotes differentiation and survival of human dendritic cells and licenses them for Th1 priming," The Journal of Immunology, vol. 174, no. 11, pp. 6820-6824, 2005.

[69] J. J. Díez and P. Iglesias, "The role of the novel adipocyte-derived hormone adiponectin in human disease," European Journal of Endocrinology, vol. 148, no. 3, pp. 293-300, 2003.

[70] S. W. Coppack, "Pro-inflammatory cytokines and adipose tissue," Proceedings of the Nutrition Society, vol. 60, no. 3, pp. 349-356, 2001.

[71] A. Kautzky-Willer, G. Pacini, A. Tura et al., "Increased plasma leptin in gestational diabetes," Diabetologia, vol. 44, no. 2, pp. 164-172, 2001.

[72] D. Simmons and B. H. Breier, "Fetal overnutrition in polynesian pregnancies and in gestational diabetes may lead to dysregulation of the adipoinsular axis in offspring," Diabetes Care, vol. 25, no. 9, pp. 1539-1544, 2002.

[73] A. Festa, N. Shnawa, W. Krugluger, P. Hopmeier, G. Schernthaner, and S. M. Haffner, "Relative hypoleptinaemia in women with mild gestational diabetes mellitus," Diabetic Medicine, vol. 16 , no. 8, pp. 656-662, 1999.

[74] M. Loukovaara, P. Leinonen, K. Teramo, H. Alfthan, U.H. Stenman, and S. Andersson, "Fetal hypoxia is associated with elevated cord serum C-reactive protein levels in diabetic pregnancies," Biology of the Neonate, vol. 85, no. 4, pp. 237-242, 2004.

[75] E. Soyland, M. S. Nenseter, L. Braathen, and C. A. Drevon, "Very long chain n-3 and n-6 polyunsaturated fatty acids inhibit proliferation of human T-lymphocytes in vitro," European Journal of Clinical Investigation, vol. 23, no. 2, pp. 112-121, 1993.

[76] F. A. Wallace, E. A. Miles, C. Evans, T. E. Stock, P. Yaqoob, and P. C. Calder, "Dietary fatty acids influence the production of Th1- but not Th2-type cytokines," Journal of Leukocyte Biology, vol. 69, no. 3, pp. 449-457, 2001.

[77] Y. T. Konttinen, V. Bergroth, E. Kinnunen, D. Nordström, and T. Kouri, "Activated T lymphocytes in patients with multiple sclerosis in clinical remission," Journal of the Neurological Sciences, vol. 81, no. 2-3, pp. 133-139, 1987.

[78] J. N. W. N. Barker, "The pathophysiology of psoriasis," The Lancet, vol. 338, no. 8761, pp. 227-230, 1991.

[79] J. E. Merrill, C. Mohlstrom, C. Uittenbogaart, V. Kermaniarab, G. W. Ellison, and L. W. Myers, "Response to and production of interleukin 2 by peripheral blood and cerebrospinal fluid lymphocytes of patients with multiple sclerosis," The Journal of Immunology, vol. 133, no. 4, pp. 1931-1937, 1984.

[80] R. E. Wolf and W. G. Brelsford, "Soluble interleukin-2 receptors in systemic lupus erythematosus," Arthritis and Rheumatism, vol. 31, no. 6, pp. 729-735, 1988.

[81] J. Bellenger, S. Bellenger, A. Bataille et al., "High pancreatic n-3 fatty acids prevent STZ-induced diabetes in fat-1 mice: inflammatory pathway inhibition," Diabetes, vol. 60, no. 4, pp. 1090-1099, 2011.

[82] T. A. Babcock, W. S. Helton, D. Hong, and N. J. Espat, "Omega3 fatty acid lipid emulsion reduces LPS-stimulated macrophage TNF- $\alpha$ production," Surgical Infections, vol. 3, no. 2, pp. 145-149, 2002.

[83] A. Denys, A. Hichami, and N. A. Khan, "Eicosapentaenoic acid and docosahexaenoic acid modulate MAP kinase enzyme activity in human T-cells," Molecular and Cellular Biochemistry, vol. 232, no. 1-2, pp. 143-148, 2002.

[84] P. C. Calder, J. A. Bond, S. J. Bevan, S. V. Hunt, and E. A. Newsholme, "Effect of fatty acids on the proliferation of concanavalin a-stimulated rat lymph node lymphocytes," International Journal of Biochemistry, vol. 23, no. 5-6, pp. 579$588,1991$.

[85] W. M. Tsang, C. Weyman, and A. D. Smith, "Effect of fatty acid mixtures on phytohaemagglutinin-stimulated lymphocytes of different species," Biochemical Society Transactions, vol. 5, no. 1, pp. 153-154, 1977.

[86] P. C. Calder, S. J. Bevan, and E. A. Newsholme, "The inhibition of T-lymphocyte proliferation by fatty acids is via an eicosanoidindependent mechanism," Immunology, vol. 75, no. 1, pp. 108$115,1992$.

[87] A. Yessoufou, A. Plé, K. Moutairou, A. Hichami, and N. A. Khan, "Docosahexaenoic acid reduces suppressive and migratory functions of $\mathrm{CD}^{+} \mathrm{CD}^{+} 5^{+}$regulatory T-cells," Journal of Lipid Research, vol. 50, no. 12, pp. 2377-2388, 2009.

[88] B. Li, A. Samanta, X. Song et al., "FOXP3 interactions with histone acetyltransferase and class II histone deacetylases are required for repression," Proceedings of the National Academy of Sciences of the United States of America, vol. 104, no. 11, pp. 4571-4576, 2007.

[89] J. Kipnis, M. Cardon, H. Avidan et al., "Dopamine, through the extracellular signal-regulated kinase pathway, downregulates $\mathrm{CD} 4{ }^{+} \mathrm{CD} 25^{+}$regulatory T-cell activity: implications for neurodegeneration," The Journal of Neuroscience, vol. 24, no. 27, pp. 6133-6143, 2004.

[90] L. Li, W. R. Godfrey, S. B. Porter et al., "CD4+CD25+ regulatory T-cell lines from human cord blood have functional and molecular properties of T-cell anergy," Blood, vol. 106, no. 9, pp. 3068-3073, 2005.

[91] C. J. Sherr, “Cancer cell cycles," Science, vol. 274, no. 5293, pp. 1672-1677, 1996. 
[92] C. Triboulot, A. Hichami, A. Denys, and N. A. Khan, "Dietary (n-3) polyunsaturated fatty acids exert antihypertensive effects by modulating calcium signaling in T cells of rats," Journal of Nutrition, vol. 131, no. 9, pp. 2364-2369, 2001.

[93] N. A. Khan and A. Hichami, "Role of n-3 polyunsaturated fatty acids in T-cell signalling," in Recent Advances in Research in Lipids, vol. 6, pp. 65-78, Transworld Publications, 2002.

[94] S. Madani, A. Hichami, A. Legrand, J. Belleville, and N. A. Khan, "Implication of acyl chain of diacylglycerols in activation of different isoforms of protein kinase C," The FASEB Journal, vol. 15, no. 14, pp. 2595-2601, 2001.

[95] A. Hichami, C. Morin, E. Rousseau, and N. A. Khan, "Diacylglycerol-containing docosahexaenoic acid in acyl chain modulates airway smooth muscle tone," American Journal of Respiratory Cell and Molecular Biology, vol. 33, no. 4, pp. 378386, 2005.

[96] S. Madani, A. Hichami, M. Charkaoui-Malki, and N. A. Khan, "Diacylglycerols containing omega 3 and omega 6 Fatty acids bind to RasGRP and modulate MAP kinase activation," Journal of Biological Chemistry, vol. 279, no. 2, pp. 1176-1183, 2004.

[97] USDA D, Dietary Guidelines Advisory Committee Report 2005, http://health.gov/dietaryguidelines/dga2005/report/.

[98] J. Who and F. E. Consultation, "Diet, nutrition and the prevention of chronic diseases," Technical Report Series 916, World Health Organization, Geneva, Switzerland, 2003.

[99] M. A. Leslie, D. J. A. Cohen, D. M. Liddle, L. E. Robinson, and D. W. L. Ma, "A review of the effect of omega-3 polyunsaturated fatty acids on blood triacylglycerol levels in normolipidemic and borderline hyperlipidemic individuals," Lipids in Health and Disease, vol. 14, no. 1, article 53, 2015. 


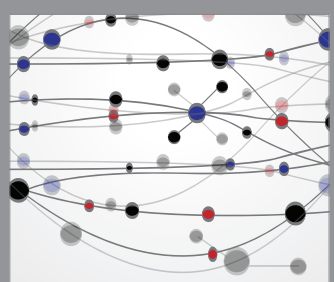

The Scientific World Journal
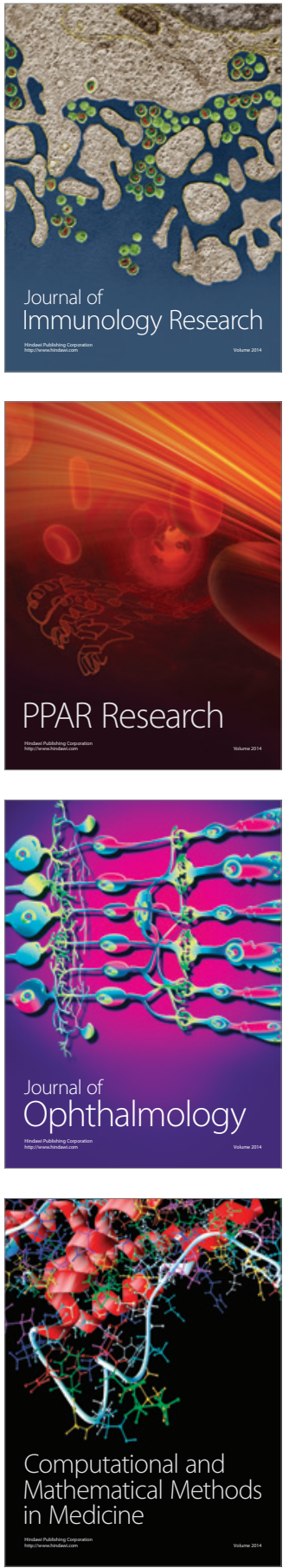

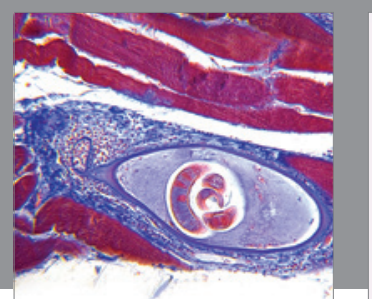

Gastroenterology Research and Practice

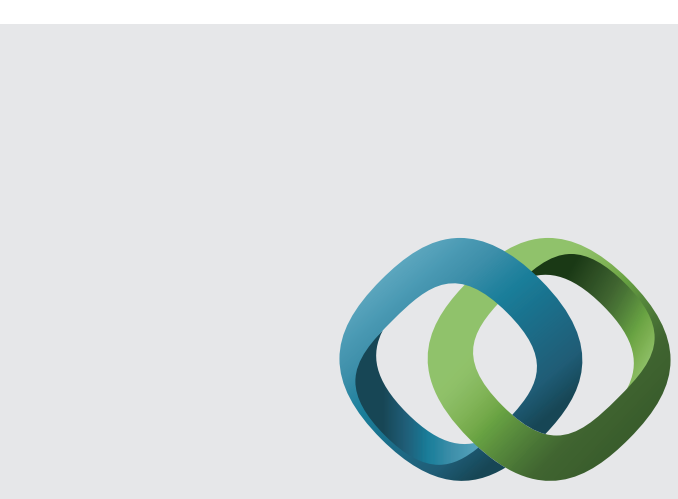

\section{Hindawi}

Submit your manuscripts at

http://www.hindawi.com
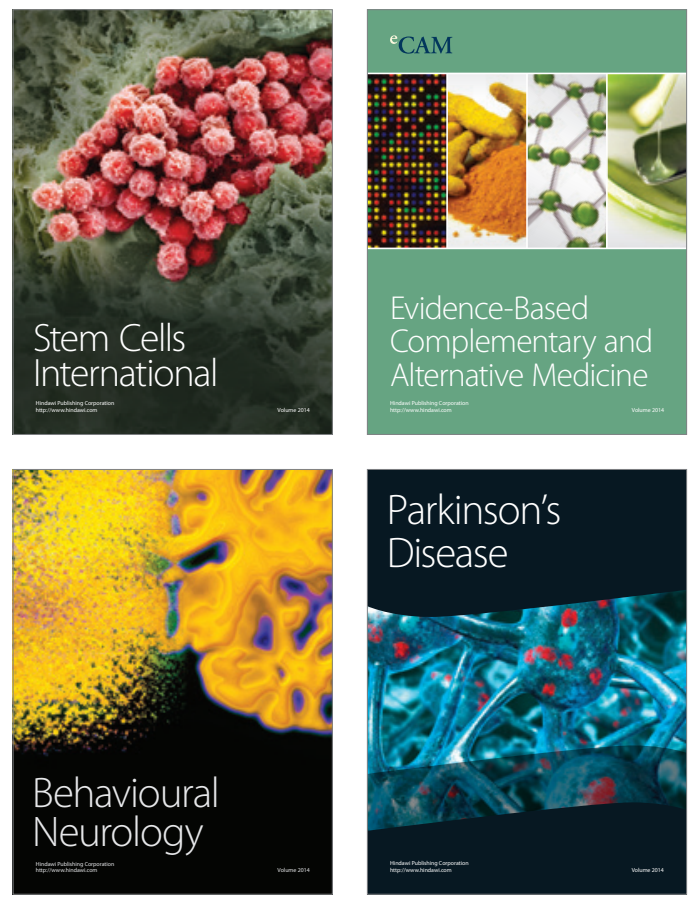
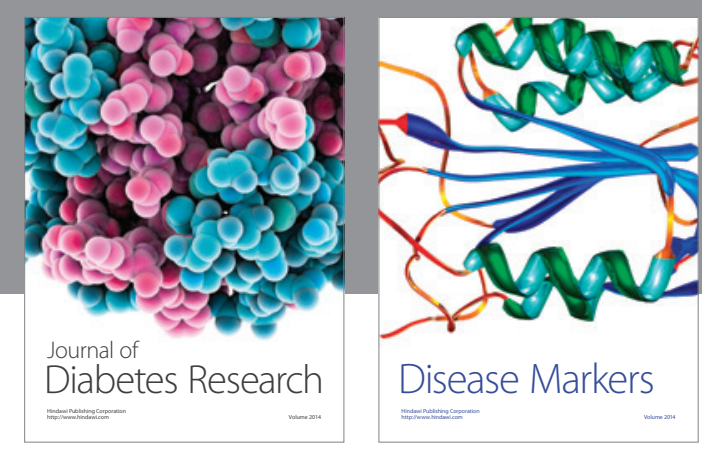

Disease Markers
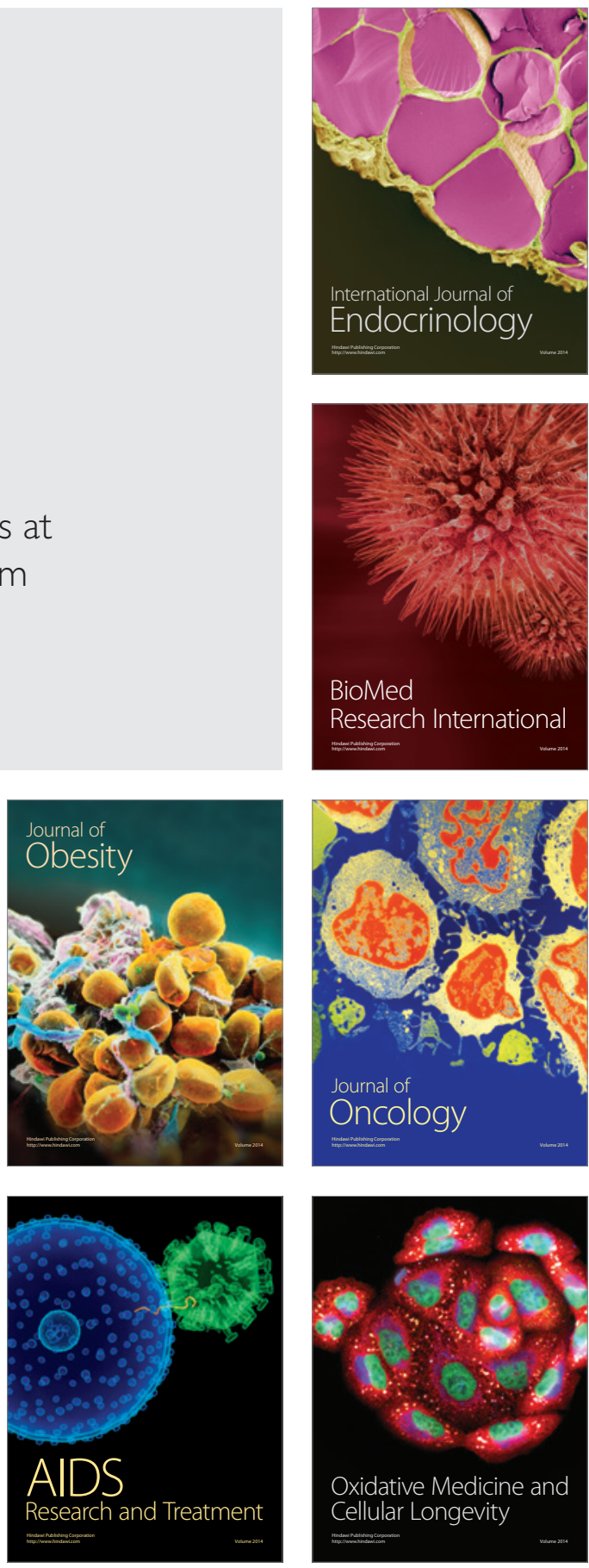